\title{
Notes on Hawks and Owls
}

\author{
by DOUG GILROY, Regina
}

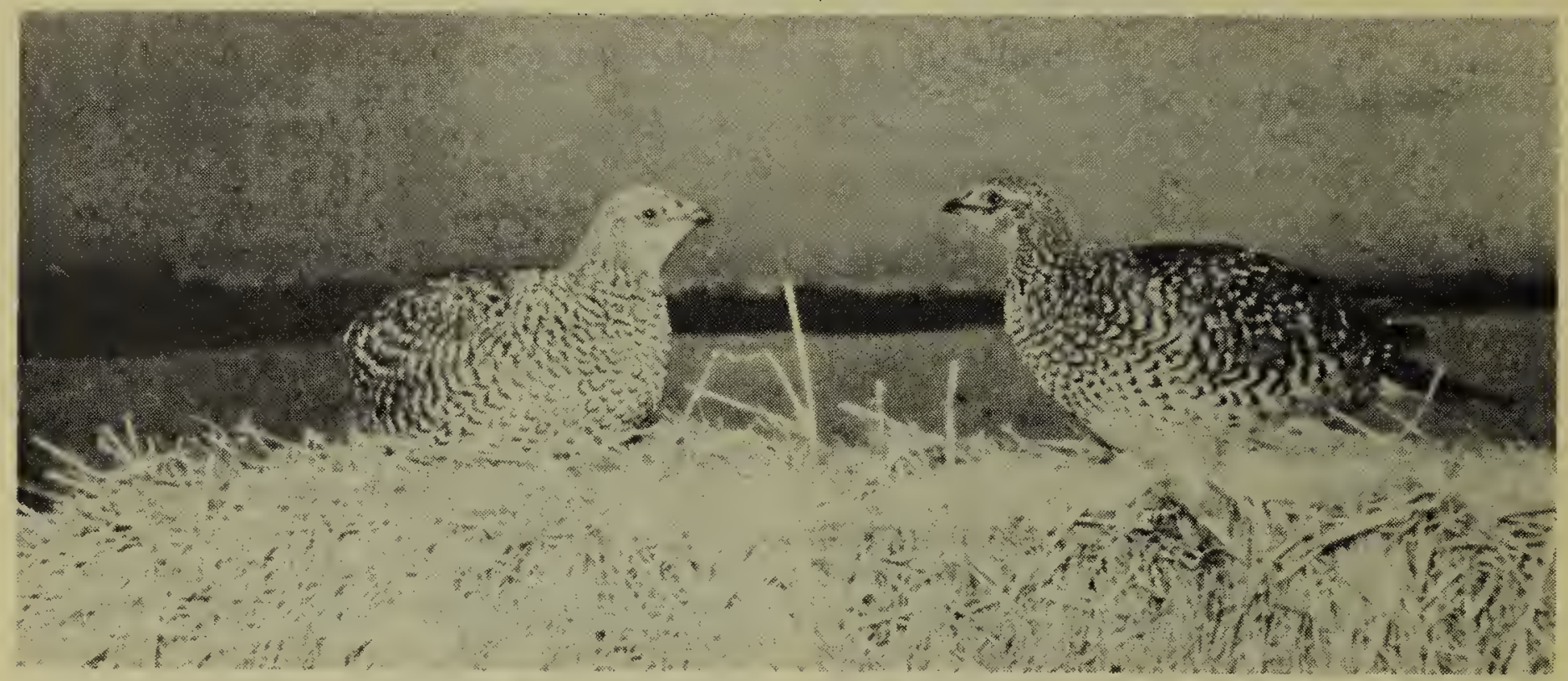

F. W. Lahrman

Recently I was asked if we have lost much poultry to winged predators. I can truthfully reply that as far as we know we have not lost one during the past fifteen years. I am not trying to say that hawks will not take poultry and I know that the Great Horned Owl is capable of killing a full gown turkey, but I do believe that our birds of prey are only about half as black as they are painted. Game birds and poultry are taken sometimes during nesting time when the birds are slaves to the appetites of growing young.

My illustration shows two Sharptailed Grouse. These are part of a flock of 21 that every morning from January 1 to the end of March came to feed in a field directly beside the house. At night and during rest hours in the day they sought shelter in a strip of woods along the creek to the south and to the west. This area was also the habitat of two Great Horned Owls whose hoots and calls could be heard on almost any calm night during the winter. The point of interest is that when spring came 21 Sharp-tailed Grouse were still feeding-not one had provided a meal for Bubo virginianus, the Great Horned Owl.

William Anaka, Spirit Lake, Sask., in a letter to the Blue Jay editor tells much the same story. "This year I have located within a mile of home: two Great Horned Owl nests, and one nest of each of Cooper's Hawk,
Red-tailed Hawk and Marsh Hawk. Despite the fact that our yard is heavily wooded we have not lost one bird this year to any feathered predator."

P. L. Beckie, Bladworth, Sask. reports some predation on birds by the Swainson Hawk. While one-waying a 100 -acre piece of stubble, which was close to many quarters of shortgrass, hilly prairie he found many Baird, Savannah, Vesper and Claycoloured Sparrow nests. There were also some half-grown Meadowlarks, Horned Larks and sparrows that were flying just well enough to escape the path of the machinery. While he was working this field a Swainson Hawk took the following six young birds: one Meadowlark, two Vesper Sparrows, two Savannah Sparrows and one Horned Lark. Mr. Beckie admits that there was some shortage of mice and that these young birds could not fly well. If the birds had not been disturbed just at this stage of their development the hawk would not likely have taken any.

Front Cover - Mr. V. Kent's picture shows a baby deer that was picked up and turned over to the Department of Natural Resources. We would like to join with wildlife management officers in urging people to refrain from touching or adopting young deer. 